УДК $821.111(73)$

\author{
Гурдуз А. I., \\ кандидат філологічних наук, доцент \\ кафедри української мови і літератури \\ Миколаївського національного університету \\ імені В. О. Сухомлинського
}

\title{
ТРИЛОГІЯ РЕНСОМА РИГГЗА ПРО ДИВНИХ ДІТЕЙ І КРИЗА МІФОТВОРЧОСТІ ПОЧАТКУ ХХІ СТОЛІТТЯ
}

У пропонованій статті вперше здійснено спробу з'ясування статусу романної серії Ренсома Риггза про дивних дітей у літературно-мистецькому прочесі початку XXI cm. Відповідно увагу зосереджено на питаннях традииї й новаторства художніх рімень $y$ трилогії порівняно з ї̈ типологічним $i /$ чи генетично зумовленим мистецьким рядом, a також на способі функціонування і ролі в цүиклі національного складника.

Ключові слова: міфотворчість, криза, модель, криптоісторія, міфопоетика, типологія, новаторство, наџіональний складник.

В предлагаемой статье впервые осуществлена попытка определения статуса романной серии Ренсома Ригzза о странных детях в литературно-художественном прочессе начала XXI века. Соответственно внимание сосредоточено на вопросах традици и новаторства решений в трилогии по сравнению с её типологическим и / или генетически обусловленным художественным рядом, а также на способе функционирования и роли в ичкле национальной составляющей.

Ключевые слова: мифотворчество, кризис, модель, криптоистория, мифопоэтика, типология, новаторство, начиональная составляющая.

In this article the attempt of the determination of the status of the novel series about the peculiar children by Ransom Riggs in the literary-art process of the beginning of the XXI century is realised for the first time. Accordingly our attention is concentrated on the questions of tradition and innovation decisions in this trilogy by comparison with its typological and / or genetic given art row. Also we analyse the way of function and the role of the national component in the named novel circle.

Keywords: mythocreation, crisis, model, cryptohistory, mythopoetics, typology, innovation, national component.

\section{Літературно-художній процес другого десятиліття XXI ст. демонструє} водночас тотальну залежність від міфотворчих проявів людської думки та 
інтенсивні пошуки нового в цій сфері при виразних симптомах кризи міфотворчості. Твори цього періоду концентрують у собі все більше елементів комбінованих, спресованих міфопоетичних рішень попереднього часу (у фокусі уваги при цьому перебуває, природно, фентезійний жанр), але в такому інтертекстуально насиченому масиві говорити про ідейний прорив або хоча б про спробу окреслення нового типу художнього мислення частіше не доводиться. Національні літератури, які на межі XX-XXI ст. шукають способи інтеграції й визнання в світовому культурному просторі (часто постколоніальні), змушені в означеному контексті вирішувати для себе непросту задачу, маючи в глобальному розумінні три основні шляхи (артикульовані нами стосовно аналогічної ситуації українського фентезіписьменника): а) кардинального національно зумовленого переосмислення систем образів - i високого ризику творчості «для домашнього вжитку»; б) адаптації й паритетного входження до світового корпусу в плані традиції (зокрема, за рахунок компромісу 3 національною складовою) та в) переосмислення ідейно-структурного плану фентезійного твору i просування національно грунтованих образних систем [Гурдуз 2014 Міжкультурний діалог:68].

Популярна романна трилогія американця Ренсома Риггза «Дім дивних дітей» - «Місто порожніх. Втеча 3 дому дивних дітей» - «Бібліотека Душ. Немає виходу 3 дому дивних дітей» 2011-2015 рр. (зі своєрідним продовженням у «Казках про дивних» 2016 р.) становить науковий інтерес як приклад маловивченого синтетичного роману перших десятиліть XXI ст.; iï текст iз вираженою комбінаторною природою міфопоетики став інваріантним для ряду пізніших творів відповідного фентезійного типу, але при цьому майже не досліджений. У нечисленних зарубіжних працях увага переважно зосереджена на аспектах історичної стилізації Р. Риггза в описах пережитих персонажами подій у період Другої світової війни, Голокосту, причому акцентована єврейська приналежність героїв, яку як ознаку незвичайності дослідники ставлять вище за надприродну особливість героїв [наприклад, див.: 
Zarzycka 2015]; має місце розгляд структури трилогії з точки зору етапності одної 3 концепцій расового часу [DiMarco 2016:110-113]. Водночас некомпаративний аналіз трилогії в цих працях кваліфікує іiі як автономну, без звертання до відповідного типологічного ряду не дозволяючи розкрити структурні особливості циклу, новизну рішень письменника, який своє бачення літературного процесу формулює так: «Книги створені іниими книгами» [Riggs 2014]. В українському науковому просторі міфопоетичні параметри трилогії про дивних дітей, особливості бінарноопозиційної побудови їі художньої тканини, характеру й ролі інтертекстуальності тощо вперше висвітлені нами [Гурдуз 2017], дослідження саме цих аспектів циклу Р. Риггза пріоритетне в силу жанрової приналежності серії та іï широкого культурного резонансу.

Метою пропонованої статті є вперше здійснювана спроба з’ясування статусу романної серії Р. Риггза про дивних дітей у літературно-мистецькому процесі початку XXI ст., для чого увагу, також уперше, зосереджуємо на а) питаннях традиції й новаторства художніх рішень у трилогії порівняно 3 іiі типологічним i/ чи генетично зумовленим мистецьким рядом та на б) способі функціонування і ролі в циклі національного складника.

Поява трилогії Р. Риггза на тлі мистецького процесу перших десятиліть XXI ст. закономірна, і тема дитини як ключового образу в ній не випадкова. Центральний концепт «дивності» героїв Р. Риггза органічний моді на «іншість», особливо проявленій у літературі й кіно з кінця ХХ ст., що має соціокультурну мотивацію. Після тріумфу реалістичних героїв, унікальність яких досягалась переважно за допомогою поєднання соціального статусу й ексклюзивних наукових інновацій (Фантомас, таємний агент 007 Джеймс Бонд, космонавт i под.), на тлі суперменівської коміксоїдної лінії набули ультрапопулярності твори про незвичайно обдарованих у силу різних факторів людей (типу «Людей-Ікс» 2000-2017рр.) чи майже людей (у циклах «Варти» 1998-2014 рр. Сергія Лук'яненка, франкенштейніани та ін.), власне ірраціональних істот (мінотавріана, вампіріада i под.). Певним оновлювальним фактором в 
окресленому художньому масиві стає образ дитини / підлітка. Масова популярність творів про незвичайних дітей кінця XX- початку XXI ст. співпадає з гіпотезами психологів про нове покоління індиго, і в мистецькому світі такий вектор проходить легко, адже дитина завжди геніальна, відповідно деякі образи юних героїв сприймаються не тільки як фантастичні, але й як метафорично гіперболізовані в потенції. Їх іншість при цьому може виражатися варіативно: це родова містична обраність і «школа» становлення особистості (у циклі про Гаррі Поттера 1997-2007 рр. англійки Джоан К. Ролінг), пародійно обіграна соціальна обраність (американська кіносерія «Діти шпигунів» 2001-2011 pр. режисера Роберта Родригієса), просто відбиток герметичності місця в душах персонажів, змушених пройти в ньому шлях випробувань (у стінах інтернату в іспанському телесеріалі Даніеля Есихи «Чорна лагуна» 2007-2010 рр. чи в елітній школі-пансіоні в адаптованій російській телеверсії «Закрита школа» 2011-2012 рр.; в коледжі - колишній психіатричній лікарні в трилогії американки Меделін Ру «Притулок» 2013-2015 рр. чи таборі для підлітків у «Домі темних загадок» («Stigmata») 2014 р. німки Беатрикс Гуріон), каліцтво як симетрична ознака обдарованості в містифікованій атмосфері (у мешканців «Дому, в якому...» армянки Маріам Петросян 1991-2009 рр.), та ін. Поряд назвемо типологічно співвідносні і генетично зумовлені цикли типу «Голодних ігор» 2008-2010 pр. Сьюзен Коллінз, «Дивергента» 2011-2013 pp. Вероніки Рот та ін., презентований якими антиутопічний художній корпус сюжетно походить від певної, розщепленої, соціальної ідеї [Гурдуз 2014:213-214]. Образ дитини чи групи дітей / підлітків пластичний i зручний для автора, може бути вписаний практично в будь-яку, особливо експериментальну, провокативну художню ситуацію: пригадаймо хоча б «Володаря мух» В. Голдинга, жорсткіші тематичні моделювання в фантастичних «Зозулятах Мідвича» Дж. Віндема 1957 p., нарешті, балансування на межі моралі у «Грі Ендера» 1985 р. - першому романі 3 однойменного циклу О. С. Карда. Як і в житті, в книзі наївна дитина викликає більшу цікавість, ображеній або переслідуваній невинній дитині більше 
співчувають i пробачають, iï поведінка більш непередбачувана i под., a порушувані в творі соціальні проблеми звучать загострено.

Формульність домінантної нині масової культури позначається на трилогії Р. Риггза, співвідносної за характером побудови художньої реальності 3 рядом попередніх аналогів, у першу чергу - названих вище творів М. Петросян і Д. Есихи, а також пізніших праць. Скажімо, віртуозно вплетена Р. Риггзом у художню атмосферу «дивних» і важлива для осягнення сюжету система фотографій - застосований прийом у творах М. Ру і Б. Гуріон; при цьому Р. Риггз, вміщуючи в текст книг фотографії всіх дивних дітей, крім фото головного героя (на думку ДіМарко, це умовне «..обличчя читача, який повинен осягнути зв'язок між часовим прогресом $i$ справедливістю» [DiMarco 2016:119]), досягає ефекту інтерактивності. Отже, цикл про дивних дітей принципово розглядати в означеному контексті як результат певного мистецького досвіду доби (такими в своїй проблемно-тематичній паралелі $\epsilon$ «Голодні ігри» С. Коллінз [Гурдуз 2014]), саме контекст підкреслює місце в ньому романів Р. Риггза, зокрема як потенційно інваріантних для пізніших творінь інших митців (так, дивує близькість назв частин циклів Р. Риггза i М. Ру), їх специфіку й новаторство. Прикметно, що вказані твори Р. Риггза, М. Петросян, Б. Гуріон і М. Ру жанрово споріднені (а для перших трьох авторів - дебютні), мають подібну і формовану значною мірою за допомогою широкої інтертекстуальної бази комбіновану міфопоетичну парадигму, порушують проблему підлітка в соціумі тощо. При цьому саме в параболічній прозі Р. Риггза масштабно звучить національна проблема і саме його трилогія стає найуспішнішим продуктом в означеній художній площині (визначальним тут можна вважати благотворний вплив «Хронік Нарнії» К. С. Льюїса улюбленого твору Р. Риггза [Riggs 2014]).

Одним 3 особливо вдалих рішень автора циклу про дивних дітей $\epsilon$ введений у текст книг елемент криптоісторії: цей хід, хоч і не будучи новим, сприяє реалізації в трилогії, крім очікуваної в форматі фентезійного масиву початку XXI ст. художньої задачі, ряду додаткових - ідеологічних - завдань. 
По-перше, у фокус уваги читача так потрапляє й фіксується тема переслідування фашистами єврейського народу часів Другої світової війни, причому кожен з головних героїв як надобдарована особистість репрезентує тут ряд різноплощинних іпостасей: i культурного героя, i соціальної жертви, i дітини, - тобто всі три названі іпостасні ряди реципієнтом сприймаються позитивно. У результаті виключність героїв як групи, що уникає загрози знищення, викликає захоплення не тільки в плані фентезійного сюжету, але й на рівні національної симпатії. По суті, в циклі Р. Риггза на противагу домінантному стереотипу американського супергероя (скажімо, чи не найбільш національно маркованого тут Капітана Америки) запропонований мистецьки вивірений подібний інонаціональний образ (характерно, що автор трилогії американець). Світовий резонанс аналізованих книг Р. Риггза та їх екранізації режисером Тимом Бертоном у 2016 р. свідчить, що успіх цього репрезентативного творіння періоду міфотворчої кризи досягається через синтез актуальної сюжетної моделі в ультрапопулярній сфері фентезі i національно зв’язаного проблемно-тематичного комплексу. Художній підхід Р. Риггза для досягнення такого ефекту - другий з трьох запропонованих нами в статті 2014 р. про перспективи розвитку українського фентезі як національного літературного авангарду [Гурдуз 2014 Міжкультурний діалог:68]: в американського митця це компромісний варіант прийняття популярних i питомих на сьогодні жанрових прийомів та іміджів персонажів (переміщення в часі умовних супергероїв у процесі їх боротьби за виживання 3 «темними» силами; до слова, підкреслює належність до «темряви» цих сил вплетений у канву трилогії біблійний контекст [Гурдуз 2017:81]) і в той же час пропозиція рельєфно прописаного в конкретному історичному просторі комплексу національних проблем єврейського народу. Художній ефект такої комбінації очевидний при зіставленні 3 романом М. Петросян (де головний герой, між іншим, - Ерик Циммерман): у «Домі, в якому...» «я постаралась прибрати не тільки географічні, але й часові прив'язки, хоча з часовими, природно, було складніме...» [Петросян 2010]. При цьому часове абстрагування в творінні 
М. Петросян, яке критика розглядає в контексті аніме і маскультурної міфології початку XXI ст. [Лебёдушкина 2010], працює згідно 3 міфопоетичними канонами як універсалізація, не дарма в італійському перекладі Е. Гуерчетті 2011 р. її твір звучить як «Дім поза часом», «Дім, де зупинився час».

У такий спосіб, успіх сприймання реципієнтом змісту книг Р. Риггза про дивних дітей багато в чому забезпечений формою піднесення інформації, тобто фентезійний антураж служить засобом актуалізації болючої історичної теми. Не говорячи про криптоісторичний складник у тексті трилогії, А. Зажицька справедливо вказує, що провокаційне оброблення теми Голокосту робить книги Р. Риггза унікальними [Zarzycka 2015]. Крім того, поєднуваність часових періодів тут працює як прийом масштабування зображуваного, і в такий спосіб герої Р. Риггза одночасно постають історично зумовленими (фізично належать своєму часу [Риггз 2016:201; Риггз 2016:250-252]; подібно виглядають у творах XX-XXI ст. епізоди появи в сучасному світі джинів, гномів i под.), i позаісторичними, а значить, порушувані в трилогії проблеми звучать універсалізовано.

Оригінальна знахідка Р. Риггза, яка забезпечує художню вібрацію образів його героїв, - оговірка, що перед читачем діти, але у плані специфічного типу розвитку, оскільки об’єктивно їм багато років (Джейкоб Портман запитує міс Перегрин: «- Ви насправді вважаєте їх дітьми? [...] -Вони самі себе вважають дітьми...» [Риггз 2016:250]). Це уможливлює філософські роздуми героїв трилогії і вписується в окреслювану автором ідеологічну площину: єврейський народ достатньо молодий духом попри його давню історію. Руйнування Дому дивних дітей також можна трактувати як певну метафору в контексті єврейської історії (до речі, в названому романі М. Петросян сам Дім теж має бути зруйнований), як і протиставлення свободи міграції вихованців міс Перегрин у часі (читай: внутрішньої свободи) їх буквальній ізольованості. Внутрішня динаміка спільноти дивних дітей досягається введенням у цей соціум постаті Джейкоба Портмана; ДіМарко справедливо вказує, що головний герой «..забезпечує для дітей мотив і спосіб залишення петлі (часу. - А. Г.), 
дорослішання $i$ прагнення закінчити утиски тих, хто, як вони, зазнає остракізм через їх іншість» [DiMarco 2016:110].

Зауважимо також, що для осягнення глибинних смислів трилогії необхідний аналіз пї оригінального тексту. Так, в українсько- i російськомовному варіантах циклу (відповідно В. Горбатька і О. Борової) при згадуванні монструозних «порожнеч» не актуалізується тема Голокосту, як в англійському тексті, де цей принциповий момент підкреслений співзвучним обігруванням Holocaust - hollowgast. До слова, в українському перекладі акценти назв частин трилогії Р. Риггза і визначення самих іï героїв - «дивні» (поряд 3 оригінальним «ресuliar») - звучать дещо знижено порівняно 3 інваріантом; російський переклад специфіку «дивності» дітей твору Р. Риггза узагалі нівелює: вони тут «странные» [Риггз 2016].

Створена в період міфотворчої кризи в європейському i північноамериканському культурному просторі, аналізована трилогія містить ключові ознаки цього періоду. Скажімо, спільнота мешканців Дому міс Перегрин - «дивних» 3 різними надздібностями - модифіковане зібрання об’єднаних на певний час спільною метою супергероїв XX - початку XXI ст. у творах типу американських «Месників» або «Фантастичної четвірки», які, в свою чергу, можна трактувати як осучаснені, травестійовані, версії розповідей про античних, язичницьких героїв чи божеств. Незвичайне сприймання реальності героями Р. Риггза і позиціонування їх у ній дозволяє вводити в твір таємничий світ іншого часопростору, чого раніше письменники досягали через розповіді чи описи привидів, чаклунів, сни i под. Криптоісторичне моделювання, презентація в циклі команди виключних героїв (у дитячій іпостасі) - також маркери кризи міфотворчості перших десятиліть XXI ст., супроводжуваної симптомами «втомленості» образів популярних нині супергероїв (чи їх «інфляиї̈» (С. Бережной)) [детальніше див.: Гурдуз 2016:49].

Для українського письменника блискучий художній досвід Р. Риггза може бути вельми корисний в умовах інтенсивного пошуку вітчизняною культурою власного шляху в міфотворчості XXI ст. Положення пропонованої 
статті заслуговують на подальше студіювання в форматі компаративних праць iз питань еволюції фентезійного мистецтва, а також тенденцій розвитку національних культурно-літературних систем XXI ст.

\section{БІБЛІОГРАФІЯ}

Гурдуз 2014 Міжкультурний діалог - Гурдуз А. І. Міжкультурний діалог як проблема українського фентезі XXI століття / А. I. Гурдуз // Науковий вісник Миколаївського державного університету імені В. О. Сухомлинського : зб. наук. пр. Сер. : Філологічні науки (літературознавство). - Миколаїв : МНУ ім. В. О. Сухомлинського, 2014. - Вип. 4.14 (111). - С. 63-69.

Гурдуз 2014 - Гурдуз А. I. Міфопоетична парадигма в трилогії Сьюзен Коллінз «Голодні ігри» / А. І. Гурдуз, І. С. Альбещенко // Studia methodologica / Тернопіл. нац. пед. ун-т імені В. Гнатюка. - Тернопіль : Наук.-ред. відділ ТНПУ ім. В. Гнатюка, 2014. - Вип. 37. Narrative pragmatics. - С. 212-217.

Гурдуз 2017 - Гурдуз А. Принципи міфопоетики трилогії Ренсома Риггза про дивних дітей / А. Гурдуз // Науковий вісник Миколаївського національного університету імені В. О. Сухомлинського. Сер. : Філологічні науки : (літературознавство) : зб. наук. пр. / за ред. О. С. Філатової. - Миколаїв : МНУ ім. В. О. Сухомлинського, 2017. - Квітень. - Вип. 1 (19). - С. 80-84.

Гурдуз 2016 - Гурдуз А. I. Трансформації франкенштейніани початку XXI століття: фентезійний акцент / А. І. Гурдуз // Літератури світу: поетика, ментальність і духовність : зб. наук. пр. ; гол. ред. С. І. Ковпік. - Кривий Ріг : ДВНЗ «Криворізький національний університет», 2016. - Вип. 7. - С. 42-51.

Лебёдушкина 2010 - Лебёдушкина О. Петросян, которую «не ждали». «Дом, в котором...» как «итоговый текст» десятилетия [Електронний ресурс] / Ольга Лебёдушкина // Дружба народов. - 2010. - № 8. - Режим доступу : http://magazines.russ.ru/druzhba/2010/8/le17.html.

Петросян 2010 - Петросян М. «Новых книг от меня ждать не стоит...» : интервью [Електронний ресурс] / М. Петросян // Частный корреспондент. 2010. - 12 апреля. - Режим доступу : http://www.chaskor.ru/article/mariam_petro syan_novyh_knig_ot_menya_zhdat_ne_stoit_15919. 
Риггз 2016 - Риггз Р. Дом странных детей : роман / Ренсом Риггз ; пер. с англ. Е. Боровой ; 2-е изд. - Харьков : Книжный клуб «Клуб семейного досуга»; Белгород : ООО «Книжный клуб „Клуб семейного досуга”», 2016. 432 с. ; ил.

DiMarco 2016 - DiMarco D. Time Appropriation and Phototextual Intervention in Ransom Riggs' Miss Peregrine's Home for Peculiar Children / Danette DiMarco // Misfit Children: An Inquiry into Childhood Belongings / ed. by M. P. J. Bohlmann. - Lankam; Boulder ; New York; London : Lexington Books, 2016. - P. 109-126.

Riggs 2014 - Riggs R. Books are made of other books: An Interview/ Ransom Riggs, Taheren Mafi ; by Allan Paul I. Carreon [Електронний ресурс]. Режим доступу: http://www.allancarreon.com/2014/05/12/books-are-made-of-otherbooks/.

Zarzycka 2015 - Zarzycka A. The Gothicization of World War II as a Source of Cultural Self-Reflection in Miss Peregrine's Home for Peculiar Children and Hollow City [Електронний pecypc] / A. Zarzycka // War Gothic in Literature and Culture ; ed. by A. S. Monnet, S. Hantke. - New York : Routledge, 2015. - 296 p. Режим доступу : https://books.google.com.ua/books?id=mKk0CwAAQBAJ\& print $\mathrm{sec}=$ frontcover $\& \mathrm{hl}=\mathrm{ru} \&$ source $=\mathrm{gbs} \_$atb $\# \mathrm{v}=$ onepage $\& \mathrm{q} \& \mathrm{f}=$ false . 